\title{
IMMUNOLOGICAL DISTURBANCE IN WEST AND LENNOX-GASTAUT SYNDROMES
}

\author{
TEREZINHA C. B. MONTELLI* \\ NORMA G. S. MOTA ** \\ M. TEREZINHA S. PERACOLI ** \\ ELZA A. TORRES ** \\ M. THEREZA REZKALLAH-IWASSO **
}

Infections are frequent in patients with West syndrome. Friedman and Pampiglione 6 found a high early mortality (1:4) due to bronchopneumonia or other infections, in children with hypsarrytmia. Riikonen ${ }^{21}$ reported that 8 out of 11 children who had infantile spasms and cytomegalovirus infection had severe recurrent respiratory infections. Millichap and Ortiz ${ }^{14}$, Hagberg 8 and Volzke et al 25 also have referred the frequency of infections in these children. Beaussart 1 related recurrent infections due to ACTH therapy and Chevrie 4 refers 14 cases of fatal infections, during hormonal therapy. The causes of such susceptibility to infections in these children are unknown. Primary hypoimmunoglobulinemia $A$ and $M$ was reported by Bugiani et al $^{3}$ in two siblings with West syndrome. In a previous paper ${ }^{18}$, we have described depressed cellular immunity in five children with secondary West syndrome.

The purpose of our investigation is to asses the extent of this immunological dysfunction in children with primary (cryptogenic) and secondary West and Lennox-Gastaut syndromes.

\section{PATIENTS AND METHODS}

The test group consisted of 30 patients aged between 4 months and 18 years with West or Lennox-Gastaut syndromes. They were all submitted to clinical, neurological, electroencephalographic and immunological evaluations. The age, sex and etiology of the illness in West and Lennox-Gastaut patients are shown in table 1. One child had a third degree protein-calorie malnutrition 18; nutritional condition of others was satisfactory. The control group for cell-mediated immunity consisted of 19 normal persons aged between 6 months and 18 years. Before immunological evaluation informed consent was obtained from the mothers of all infants enrolled in the study. Immunological tests were planned to avoid the interference of ACTH therapy. Sensitization with dinitrochlorobenzene (DNCB), intracutaneous test with phytohaemagglutinin (PHA) and "in vitro" tests were made two days prior to ACTH therapy, in children with West syndrome. The challenge with DNCB was made 18 to 60 days after the end

Department of Neurology (*) and Department of Immunology (**), IBBMA-UNESP. 


\begin{tabular}{|c|c|c|c|c|c|c|}
\hline \multirow{2}{*}{ Syndrome } & \multirow{2}{*}{$\begin{array}{l}\text { Number of } \\
\text { patients }\end{array}$} & \multirow{2}{*}{$\begin{array}{l}\text { Median age } \\
\text { (total range) }\end{array}$} & \multicolumn{2}{|c|}{ Sex } & \multicolumn{2}{|c|}{ Etiology } \\
\hline & & & Male & Female & Primary & Secondary \\
\hline West & 18 & $\begin{array}{l}11 \text { months } \\
\text { (4 months - } \\
3 \text { years) }\end{array}$ & 10 & 8 & 3 & 15 \\
\hline Lennox-Gastaut & 12 & $\begin{array}{c}5 \text { 1/2 years } \\
\text { (3 years - } \\
18 \text { years) }\end{array}$ & 5 & 7 & 3 & 9 \\
\hline
\end{tabular}

Table 1 - Distribution of West and Lennox-Gastaut patients according to age, sex and and etiology of the illness.

of ACTH therapy. Lennoux-Gastaut patients were submitted to immunological evaluation when not receiving ACTH. It was impossible to avoid the interference of anti-epileptic drugs. The medication consisted in combinations of phenobarbital with nitrazepan or clonazepan or valproic acid.

Immunoglobutin levels - Quantitative determinations of IgG, IgA and IgM were carried out by single radial immunodiffusion, according to Mancini et al 11, using "Partigen Plates" (Behringwerke, Marburg) and the results expressed in $\mathrm{mg} / \mathrm{ml}$. The Ig values were compared with standard values for Brazilian population in different age ranges, as described by Irulegui et al 9. Cell-mediated immunity evaluation "In vivo" tests: intracutaneous tests with $2 \mu$ g of PHA (Wellcome, England) were carried out according to Bonforte et al 2. The reactions were read at $24 \mathrm{~h}$, and the two largest diameters of induration were measured in millimeters. A positive reaction was defined as a mean diameter $\geqslant 5 \mathrm{~mm}$. Sensitization with DNCB was accomplished according to Mendes et al 12. Sensitizing doses of $2000 \mu \mathrm{g}$ of DNCB dissolved in 0.1 $\mathrm{ml}$ of acetone were spread and mantained over a $2 \mathrm{sq} \mathrm{cm}$. area of skin, on the back of patients for $48 \mathrm{~h}$. Eighteen or more days later, excluding the ACTH therapy days, a patch test was made with $100 \mu \mathrm{g}$ of DNCB in acetone, on a skin site different from the one used for sensitization. Skin reactions consisting of erythema and induration at $48 \mathrm{~h}$ were accepted as evidence of sensitization. This test was not performed in control patients due to ethical reasons. " $I m$ vitro" tests: $T$ and $B$ peripheral blood lymphocytes were studied by rosette formation, as described by Mendes et al. 13. Inhibition of peripheral leucocyte migration in presence of PHA (10 $\mu \mathrm{g} / \mathrm{ml}$ ) was performed according to Morison 16. The results were expressed as leucocyte migration index, which is the ratio: (mean area of migration with PHA/ mean area of migration without PHA) $x$ 100. Lymphocyte cultures were performed according to Musatti et al 17. The stimulating agent employed was PHA-P (Difco, 1:100 dilution) and the results were expressed as blastogenic index, wich is the ratio: cpm of stimulated tubes/cmp of control tubes. 


\section{RESULTS AND DISCUSSION}

The polyclonal stimulation of lymphocytes by PHA was depressed (blastogenic index $<15$ ) in 10 out of 18 patients $(55 \%)$ with West syndrome (Fig. 1). The majority of Lennox-Gastaut patients (78\%) presented a good response to PHA stimulation. In this study lymphocyte transformation was little influenced by the patient's plasma. We detected blastogenic inhibition activity in one out of 8 cultures of West patients performed in both autologous and homologous plasma. This inhibitory activity was detected when the blastogenic index was reduced in patient's plasma compared to normal plasma. Our findings suggest that depressed blastogenic response to PHA may be the consequence of a intrinsic $T$-cell dysfunction. The percentage of $T$ lymplocytes was significantly lower in West and Lennox-Gastaut patients than in controls (Fig. 2). No alteration in the proportion of $B$ lymphocytes was observed in these patients. In our study, leucocyte migration inhibition test in the presence of PHA was

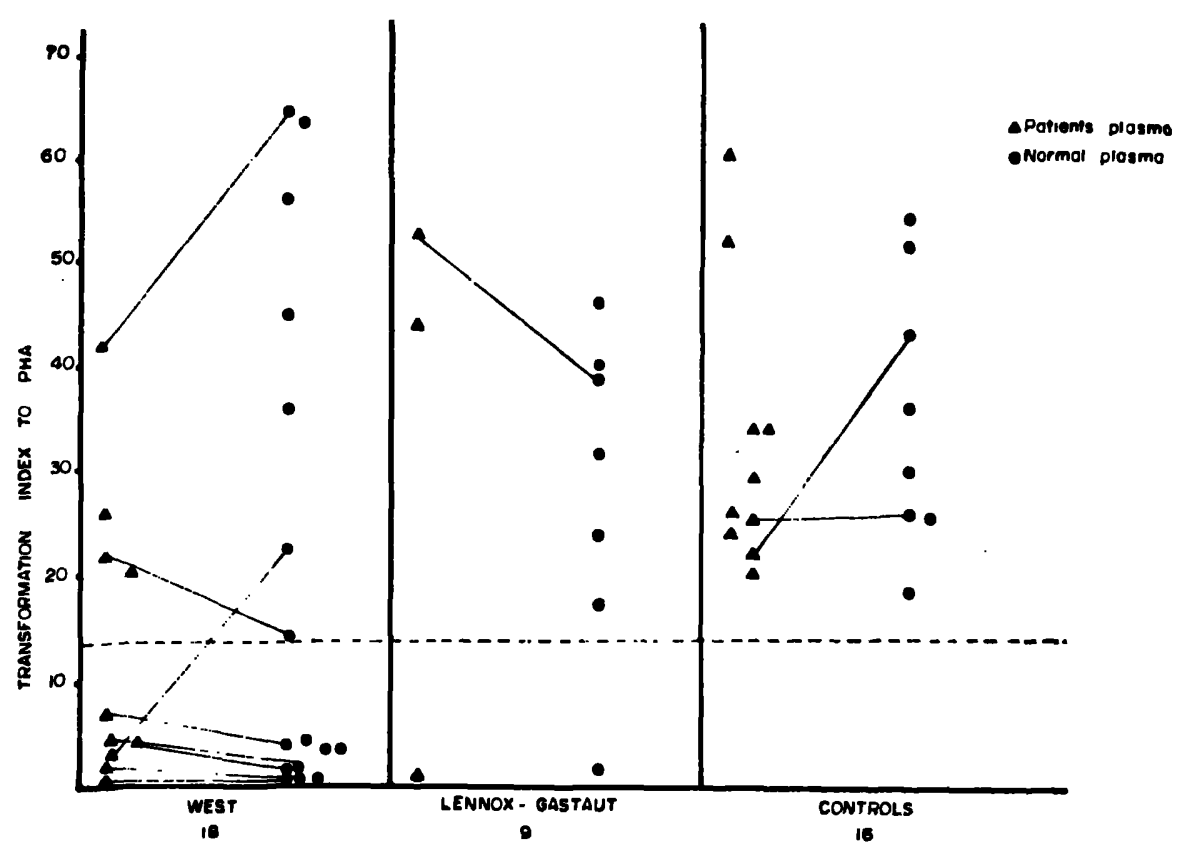

Fig. 1 - Lymphocyte blastic transformation index to PHA, in healthy controls, West and LennoxGastaut patients. Solid line shows simultaneous cultures of the same patient, containing either patient or normal plasma. Statistical analysis by MannWhitney $U$ Test. (Control $x$ West) p $<\quad 0.025$. Values above dotted lines were considered as positive.
Fig. 2 - Percentage of $T$ and $B$ peripheral blood lymphocytes, in healthy controls, West and Lennox-Gastaut patients. Statistical analysis by Mann-Whitney $U$ Test. $T$ cells: (West $x$ Control) $p<0,05$; (Control $x$ Lennox) $p<0.05$. Horizontal bars represent the median value.

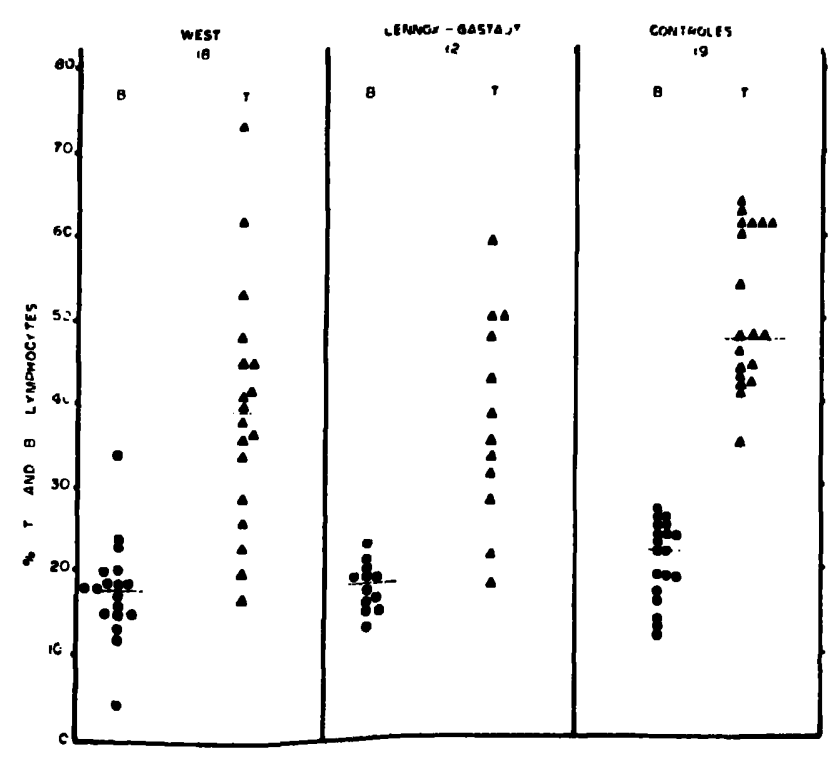


found to be slightly depressed only in West syndrome (Fig. 3). These data suggest a defect in lymphokine production in this group of patients. Results of delayed cutaneous reactions to PHA and DNCB are shown in Table 2. The percentage of positive response to PHA was significantly lower in patients with West syndrome than in normal controls. The high frequency of positive reactions observed in our control group is similar to that reported by Benforte et $\mathrm{al}^{2}$ and Lawler et al ${ }^{10}$. Reactivity to DNCB was reduced in both groups of patients, specially in that with West syndrome. DNCB sensitization has been reported to be positive in $87 \%$ of normal children of $1-5$ years of age 23 and in $92 \%$ of children aged between 1-17 years ${ }^{22}$. It is remarkable that cutaneous reaction to $\mathrm{DNCB}$ was the more sensitive parameter to detect immunodeficiency in our patients. A negative $D N C B$ sensitization test may be atrributable to either impairment of afferent or efferent limb of the immune response 20.

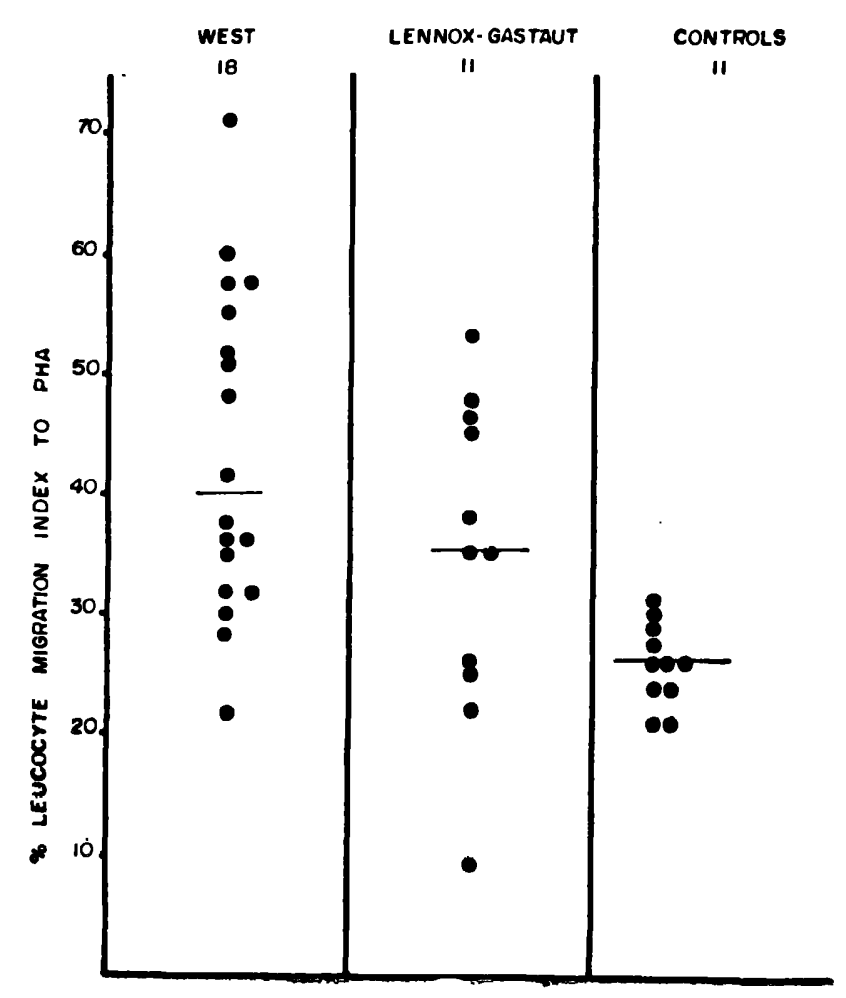

Fig. 3 - Leucocyte migration index to $P H A$, in healthy controls, West and Lennox-Gastaut patients. Statistical ancilysis by ManmWhitney $U$ Test. (Control $x$ West) $p<0.05$; horisontal bars represent the median value.

\begin{tabular}{lcc}
\hline \multirow{2}{*}{ Group } & \multicolumn{2}{c}{$\%$ Positive reactions } \\
\cline { 2 - 3 } & DNCB & PHA \\
\hline \hline West & $12(2 / 16)$ & $66(10 / 15)^{*}$ \\
Lennox-Gastaut & $50(5 / 10)$ & $88(8 / 9)$ \\
Control & N. D. & $100(12 / 12)$ \\
\hline
\end{tabular}

Table 2 - Percentage of positive cutaneous reaction to DNCB and PHA in West and Lennox-Gastaut patients. Statistically different from control (p=0.0s7) as determined by Fischer exact probability test; N.D. = not determined.

Table 3 shows the number of depressed cell-mediated immunological tests per patient. Few children treated on a outpatient basis had not all the tests performed, due to lack in the previously estipulated return days. So, these 


\begin{tabular}{lcccccc}
\hline Group & $\begin{array}{c}\text { Number of } \\
\text { patients }\end{array}$ & \multicolumn{4}{c}{ Number of depressed tests } \\
\cline { 2 - 6 } & 18 & 0 & 1 & 2 to 3 & 4 to 5 \\
\hline West & 12 & 0 & 3 & 9 & 6 \\
Lennox-Gastaut & 2 & 3 & 6 & 1 \\
\hline
\end{tabular}

Table 3 - Number of depressed cell-mediated tests per patient in West and Lennox-Gastaut symdromes.

numbers may represent minimal deficits. We considered depressed values those below the total range of controls. It is noteworthy that all cases of West syndrome showed depression in at least one out of 5 tests of cellular immunity. $T$ cell dysfunction in children with Lennox-Gastaut syndrome was less severe, with only one patient exhibiting pronounced immunosupression (4-5 depressed test). Our results also demonstrated that the impairment of cellular immunity varies from pationt to patient. Similar findings has been reported in ataxia-telangiectasia ${ }^{18}$, but reason for such variability in the immune deficits remains unknown. Depressed cellular immunity has been described in some neurological disorders, such as primary gliomas, subacute sclerosing panencephalitis and ataxia-telangiectasia ${ }^{19}$. The significance of this association is not clearly understood.

Figure 4 shows IgG, IgA and IgM levels in the groups studied. Shaded areas indicate normal mean \pm total range in accordance with standard values for Brazilian population in different age ranges. Patients above and below 3 years of age are plotted separately, with appropriate normal areas (10 controls in each group). We found few cases of depressed immunoglobulin levels in our patients. Low levels of IgG, IgA and IgM were detected in $10 \%$ of West patients whereas only one Lennox patient presented hypoimmunoglobulinemia $G$. These findings contrast with those refered by Tartara et al $\mathbf{2 4}$ who studied serum immunoglobulin levels in 86 epileptic patients. They found depressed
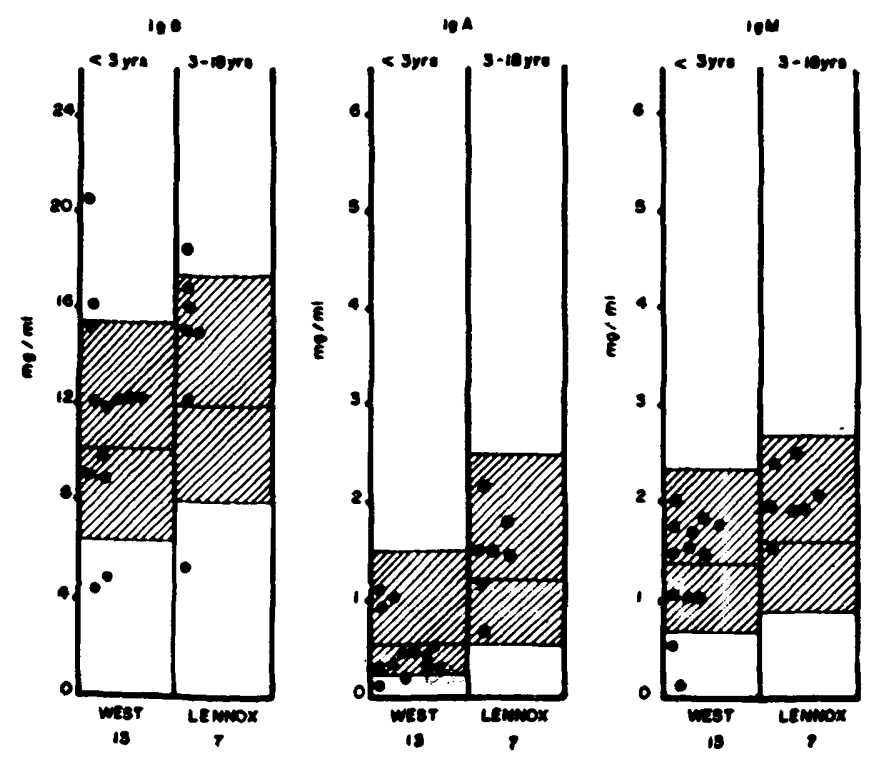

Erig. 4 - Serum immunoglobulin levels in West and Lennox-Gastaut syndromes. Shaded areas indicate norinal mean \pm total range. 
values in $42.4 \%$ of cases, not related to clinical type of epilepsy. On the other hand, Bugiani et al $^{3}$ reported primary deficiency of $\operatorname{IgA}$ and $\operatorname{IgM}$ in two siblings with West syndrome.

The degree of depression of cellular and humoral immunity in West and Lennox-Gastaut syndromes correlates with their predisposition to infections. In 9 children, infections were so frequent and serious that the overshadow neurological symptoms (broncopneumoniaes, diarrheas, meningitis, urinary infections, mycosis). It was surprising, therefore, to find that at the opposite extreme there were 6 children that had not an increase in susceptibility to infections when compared with normal individuals. Intermediate susceptibility to infections, such as one episode of bronchopneumoniae or urinary infections, was also found in 15 children.

There was no association with malignancy except for one child, in which retinoblastoma was diagnosed at the same time that West syndrome. In one case of West syndrome, previously described in detail ${ }^{15}$, the cell-mediated deficiency was diagnosed prior to the onset of the flexion spasms. The immunological evaluation of three children was performed without any medication. Changas of immunological behavior induced by phenobarbital do not seem to occur 5,7. Benzodiazepines and valproic acid effects on immunological function, have not been defined, to our knowledge. The immunological dysfunction detected in this study confirms our previous report 15 that the thymus-dependent immune response is frequently depressed in West syndrome and extends this observation to Lennox-Gastaut syndrome.

\section{SUMMARY}

Cell-mediated and humoral immunity were investigated in 18 patients with West syndrome, 12 with Lennox-Gastaut syndrome and 19 healthy controls. The study included determination of $T$ and $B$ peripheral blood lymphocytes, serum levels of $\operatorname{IgG}, \operatorname{IgA}$ and $\operatorname{Ig}$, skin sensibilization with DNCB, intracutaneous PHA, leucocyte migration inhibition test and lymphocyte blastic transformation in the presence of PHA. Cell-mediated deficiency was detected in 28 children whereas low levels of immunoglobulins were observed only in 6 children. Immunological disturbances were more prominent in children with West syndrome.

\section{RESUMO}

\section{Distürbios imunológicos nas sindromes de West e Lennox-Gastaut.}

Investigamos a imunidade humoral e celular em 18 pacientes com sindrume de West, 12 com sindrome de Lennox-Gastaut e 19 controles. Os exames realizados foram os seguintes: percentagem de linfócitos $T$ e $B$ no sangue periférico, niveis séricos de IgG, IgA e IgM, sensibilização cutânea com o DNCB, PHA intra dérmica, teste de inibição de migração de leucócitos e transformação blástica de linfócitos em presença de PHA. 
Detectamos deficiência de imunidade celular em 28 crianças, (18 com sindrome de West e 10 com sindrome de Lennox-Gastaut) e baixos níveis de imunoglobulinas em apenas 6 .

A depressão imunitária mostrou-se mais intensa nas crianças que apresentam sindrome de West.

\section{REFERENCES}

1. BEAUSSART, M. - Encephalopathie myoclonique du nourrison avec hypsarrhythmia: étude EEG, avant et après traitement par ACTH. Rev. neurol. (Paris) 103:243, 1960.

2. BONFORTE, R. J.; TOPILSKY, M.; SILTZBACH, L. E. \& GALDE, P. R. Phytohemagglutitinin skin test: a possible in vivo measure of cell-mediated immunity. J. Pediatrics 81:775, 1972.

3. BUGIANI, O.; TOSO, V.; GATTI, R.; MANCARDI, G. L. \& LEONARDI, A. Primary immunodeficiency with early encephalopathy in two siblings. Eur. Neurol. 13:405, 1975.

4. CHEVRIE, J. J. - Syndrome de West. Encycl. Med. Chir. Neurologie 17045 A 80, 5. Paris, 1979.

5. FONTANA, A.; GROB, P. J.; SAUTER, R. \& JOLLeR, H. - IgA deficiency, epilepsy and hydantoin medication. Lancet $2: 228,1976$.

6. FRIEDMAN, E. \& PAMPIGLIONE, E. - Prognostic implications of EEG findings of hypsarrhythmia in first year of life. Brit. med. J. 4:32, 1971.

7. GROB, P. J. \& HEROLD, G. E. - Immunological abnormalities and hydantoins. Brit. med. J. 2:561, 1972.

8. HAGBERG, B. - The librium analogue Mogadon in the treatment of epilepsy children. In Proccedings of the eigtenth Congress of Scandinavian Neurologists. Helsinki. Acta neurol. scand. (suppl.) 31:167, 1967.

9. IRULEGUI, I.; FERRI, R. G.; BARBIERI, D.; QUARENTEI, G.; GONZALES, C. H.; PENNA, H. A. O.; CORRADINI, H. B.; PENNAPHIM, D. \& LAGOA, N.' - Immunoglobulins in normal children by immunoelectrophoresis and quantitative radial immunodiffusion: values from birth to three years. Rev. Hosp. Clin. Fac. Med. S. Paulo 30:198, 1976.

10. LAWLOR, G. J., Jr.; STIEHM, E. R.; KAPLAN, M. S.; SENGAR, D. P. S. \& TERASAKI, P. I. - Phytohemagglutinin (PHA) skin test in the diagnosis of cellular immunodeficiency. J. Allergy clin. Immunol. 52:31, 1973.

11. MANCINI, G.; CARBONARA, H. O.; HEREMANS, J. F. - Immunochemical quantification on antigens by single radial immunodiffusion. Immunochemistry 2:235, 1965.

12. MENDES, E.; RAPHAEL, H.; MOTA, N. G. S. \& MENDES, N. F. - Cell-mediated immunity in leprosy and transfer of delayed hipersensivity reactions. J. Allergy clin. Immunol. 53:233, 1974.

13. MENDES, N. F.; MIKI, S. S. \& PEIXINHO, Z. F. - Combined detection and human $T$ and $B$ lymphocyte by rosette formation with sheep erythrocytes and

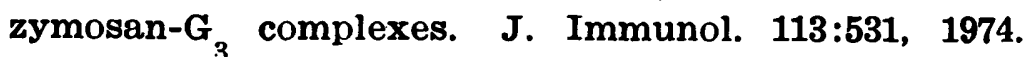

14. MILLICHA ${ }^{3}$, J. G. \& ORTIZ, W. R. - Nitrazepan in mioclonic epilepsies. Amer. J. Dis. Child. 112:242, 1966.

15. MONTELLI, T. C. B.; RezKallah-IWASSO, M. T.; PERACOLI, M. T. S. \& MOTA, N. G. S. - Cell-mediated and humoral immunity in West syndrome. Arq. Neuro. Psiquiat. (São Paulo) 39:1, 1981.

16. MORISON, W. L. - Effect of phytohaemagglutinin in the leucocyte migration inhibition test as a mesure of cell-mediated immunity. J. clin. Pathol. 27:113, 1974.

17. MUSSATTI, C. C.; REZKALlaH, M. T.; MENDES, E. \& MENDES, N. F. - In vivo and in vitro evaluation of cell-mediated immunity in patients with paracoccidioidomycosis. Cell. Immunol. 24:365, 1976. 
18. NEUWELT, E. A. \& KEMP CLARK, W. - Ataxia teleangiectasia (chap 5). In: NEUWELT, E. A.; KEMP CLARK, W. (eds.) Clinical aspects of neuroimmunology. Willians \& Wilkins, 1978. p. 120.

19. NEUWELT, E. A. \& KEMP CLARK, W. - Methods and techniques important in neuroimmunology (chap 2). In: NEUWELT, E. A.; KEMP CLARK, E. (eds.) Clinical aspects of neuroimmunology. Willians \& Wilkins, 1978. p. 15.

20. NIWA, Y.; NIWA, H.; HOHMURA, J.; OU, D. W. YOKOYAMA, M. M. - Studies on the dinitroclorobenzene (DNCB) sensitization test. Ann. Allergy 48:108, 1982.

21. RIIKONEN, R. - Cytomegalovirus infection and infantile spasms. Develop. Med. Child. Neurol. 20:570, 1978.

22. RYNIEWICZ, B. \&' PAWINSKA, M. - Preliminary immunological studies in spinal muscular atrophy. Eur. J. Pediatr. 128:57, 1978.

23. SANJEEV RAI, B.; KRISHNAMURTHY, P. N. \& RAMA RAO, B. R. - Study of cell-mediated immunity in malnourished children using DNCB skin sensitization test. Ind. Pediatr. 18:29, 1981.

24. TARTARA, A.; VERRI, A. P.; NESPOLI, L.; MOGLIA, A. \& BOTTA, M. G. Immunological findings in epileptic and febrile convulsion patients before and under treatment. Eur. Neurol. 20:306, 1981.

25. VOLZKE, E.; DOOSE, H. \& STEPHAN, E. - The treatment of infantile spasms and by hypsarrhythmia with Mogadon. Epilepsia 8:64, 1967.

Departamento de Neurologia IBBMA, UNESP - 18610 Rubiðo Junior, Botucatu, SP - Brasil. 